\title{
PROF. DR. ASLAN GÜNDÜZ’Ü SEVGİ VE RAHMETLE ANIYORUZ
}

Bir yıl önce idi...... Çalışma azmi, kararlılı̆̆ ve yurt sevgisi ile dolu genç bir hukukçu olan Prof. Dr. Aslan GÜNDÜZ, 54 yılltk kısa ömründe önüne çıkan tüm imkansızlıkları yenmeyi başarmasına rağmen, yakalandığı amansız hastalığa boyun eğmiş ve aramızdan ayrılmıştı. Akademik yaşamının bir bölümünü hasrettiği Marmara Üniversitesi Ailesi, 1994'de “üstün başarı ödülü̈”ne layık gördüğü bu genç hukukçuyu kaybetmenin derin acısını yaşadı. Bizimle birlikte, Türk yükseköğretimi büyük bir bilim adamını; hukuk camiası, genç bir meslektaşını, dostları örnek bir yakınlanını, GÜNDÜZ Ailesi ise, yeri doldurulamayacak bir bireyini kaybetti. Zaman, özlemleri azaltur, acılart dindirir denilirse de aradan tam bir yul geçti ve ne kendisine duyduğumuz özlem azald, ne de yokluğuna acısı dindi.

O'nu nasıl unutabilirdik? 1984-2001 yılları arasındaki 17 yılda üniversitemizin Hukuk Fakültesi'nde ders vermiş; idari görevler üstlenmişti. Bu yıllar arasında Devletler Hukuku Anabilim Dalı Başkanlığı'na getirilmiş; 1988-1991 yıllanı arasında Avrupa Topluluğu Enstitüsü Müdür Yardımcısı; 1994-1995'de dekan yardımcısı; 1995-2000 yılları arasında yine Avrupa Topluluğu Enstitüsü'nde, bu defa müdür olarak görev yapmışt1. 1996-2000 yıllan arasında da, üniversitemizin İnsan Hakları Merkezi Müdürü idi.

Yaşasaydı ve hukuka gönül vermiş gençliği aydınlatmaya devam etseydi. 17 Aralık 2004 günü, ülkesinin attığı tarihi adıma tanık olsaydı. Yaşasaydı ve Ekim 2005'de başlayacak Türkiye-Avrupa Birliği müzakereleri için titizlikle aranan uzman kadrodaki yerini alsaydi. 1980'den 1993'e değin, La Haye'den, Virginia'ya, Avrupa ve ABD Üniversiteleri'ne, Avrupa Konseyi' ne ve $\boldsymbol{B} M$ 'e uzanan başarılı burslarla dolu yaşamında, uluslararası

* Prof. Dr., Marmara Üniversitesi Rektörü 
hukukta kazandığı o büyük birikimi, ülkesi için değerlendirebilse idi. Bilgili deneyimli, kendinden emin, İngilizce'ye hakim, ulusal ve uluslararası alanda tanınmış bir bilimi adamı olarak, 2000'li yılların Türkiyesi'nde, çağdaş hukuk temelinde fikirleri ve kalemi ile varlığını sürdürebilseydi. Dahası, yaşasaydı ve bizi bu kadar genç yaşta terk etmeseydi.

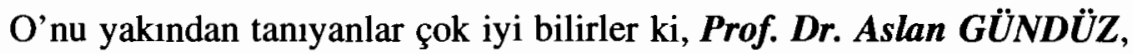
yurt içi yada yurtdışında olduğu her dönemde, önce mesleğini ve Türkiye'yi düşünürdü. Ülkesinin milli davalarını, önceliklerini, kendi hayatından üstün görürdü. Hatalı̆̆ının ilerlediği, ölümün soğuk yüzünü gösterdiği günlerde dahi, baskısı yeniden yapılacak Milletlerarası Hukuk ve Milletlerarası Teşkilatlar Hakkında Temel Metinler Kitabı'nı tamamlayamamak kaygısı, sağlığından önde gelmişti.

Ve 2004'ün soğuk bir kış günü, tabutu Türk Bayrağı'na sarılan Prof. $G \ddot{U} N D \ddot{U} Z$ 'ü, çok sevdiği vatan toprağındaki ebedi istiratgahına koyan kalabalıklar, yaşarken sevilmenin ve takdir edilmenin yüceliğini kanıtladılar. Aynı dostlar, vefatının ilk yıldönümünde, aziz hatırasına saygının en güzel kanıtı olarak bu kitabı hazırladılar. Bir dönem yöneticisi olduğu M. ̈̈. Avrupa Topluluğu Enstitïsï tarafından hazırlanan eser, kanımca gerçek bir vefa örneğidir. Bu nedenle, çalışkanlığı kadar, kıymetbilir kişiliği ile de tanınmış Enstitü Müdürüi Prof. Dr. Muzaffer DARTAN'ı ve esere emeği geçenleri içtenlikle kutluyor, şükranlarımı sunuyorum. Prof. Dr. Aslan GÜND ÜZ'ü bir kere daha rahmetle anarken, eşi Kezban Hanımefendi ile çocukları Kaan ve Baran'a sabırlar dilerim. Ruhu şad olsun. 